\title{
Use of RT-PCR for diagnosis of infectious salmon anaemia virus (ISAV) in carrier sea trout Salmo trutta after experimental infection
}

\author{
M. Devold, B. Krossøy, V. Aspehaug, A. Nylund* \\ Department of Fisheries and Marine Biology, University of Bergen, 5020 Bergen, Norway
}

\begin{abstract}
The emergence of infectious salmon anaemia virus (ISAV) in Canada and Scotand and frequent new outbreaks of the disease in Norway strongly suggest that there are natural reservoirs for the virus. The main host for the ISA virus is probably a fish occurring in the coastal area, most likely a salmonid fish. Since sea trout is an abundant species along the Norwegian coast, common in areas where ISA outbreaks occur, and possibly a life-long carrier of the ISA virus, a study was initiated to evaluate reverse transcriptase polymerase chain reaction (RT-PCR) for diagnosis of the virus in experimentally infected trout. Several tissues (kidney, spleen, heart and skin) were collected from the trout during a $135 \mathrm{~d}$ period. The following diagnostic methods for detection of the ISA virus were compared: cell culture (Atlantic Salmon Kidney, ASK cells), challenge of disease-free salmon with blood from the infected trout, and RT-PCR. The RT-PCR was the most sensitive of these methods. With the help of this technique it was possible to pick out positive individuals throughout the experimental period of $135 \mathrm{~d}$ Challenge of disease-free salmon were more sensitive than cell culture (ASK cells). These 2 latter methods require use of the immunofluorescent antibody test (IFAT) or RT-PCR for verification of presence of ISA virus.
\end{abstract}

KEY WORDS: Infectious salmon anaemia virus - Salmo trutta $\cdot$ RT-PCR · Carrier

\section{INTRODUCTION}

The emergence of infectious salmon anaemia virus (ISAV) in Canada (Mullins et al. 1998) and Scotland (Rodger et al. 1998) and frequent new outbreaks of the disease in Norway strongly suggest that there are natural reservoirs for the virus, probably in wild fish occurring in coastal area in the North Atlantic. The ISA virus has been shown to replicate in Atlantic salmon Salmo salar, sea trout $S$. trutta and rainbow trout Oncorhynchus mykiss and it cannot be excluded that the virus may also replicate in other species of Oncorhynchus (Thorud \& Djupvik 1988, Hovland et al. 1994, Nylund et al. 1994a,b, 1995a,b,c, 1996, 1997, Nylund \& Jakobsen 1995, Rolland \& Nylund 1998). A few nonsalmonid fish (turbot Scophthalmus maximus, sea bass Dicentrarchus labrax, goldsinny Ctenolabrus rupestris,

•Corresponding author. E-mail: are.nylund@ifm.vib.no and ballan wrasse Labrus bergylta have been tested and found to be negative with respect to virus replication after challenge with ISA virus (Thorud \& Torgersen 1994, Kvenseth 1998, authors' pers. obs.).

The classification of the virus has not yet been completed, but according to morphology (Hovland et al. 1994, Dannevig et al. 1995, Nylund et al. 1995a, Koren \& Nylund 1997), biochemical characteristics (Falk et al. 1997, 1998), genomic organisation (Mjaaland et al. 1997), and the sequence of the RNA polymerase (Krossøy et al. 1999), it is most likely an orthomyxovirus. It has been shown that aquatic birds are the source of all influenza A viruses in other species (Fields et al. 1996). However, due to a low optimal temperature for the growth of ISA virus (Falk et al. 1997), the main host or reservoir species is probably a vertebrate with low body temperature and most likely a salmonid fish.

Atlantic salmon, sea trout and rainbow trout are all potential carriers or reservoir species. Outbreak of ISA 
in Norwegian salmon culture, in areas where rainbow trout is not present, indicates that this is not the main reservoir species along the Norwegian coast. With the exception of 1 individual (mature male several months after challenge) it has not been possible to show the presence of ISA virus in salmon that have survived an infection, not even after injection with stress hormones (prednisolone acetate) (authors' pers. obs.). This leaves the sea trout as the most likely carrier species in Norwegian waters. It is an abundant species along the Norwegian coast, common in areas where ISA outbreaks occur, and possibly a life-long carrier of the ISA virus (cf. Nylund et al. 1995b).

The aim of this study was to develop a rapid and sensitive RT-PCR for diagnosis of the ISA virus in carrier sea trout Salmo trutta. This method is compared with cell culture (Atlantic Salmon Kidney [ASK] cells) and challenge of disease-free salmon with blood from the infected trout.

\section{MATERIALS AND METHODS}

Sea trout Salmo trutta and salmon smolts $S$. salar were supplied by 2 different smolt hatcheries close to Bergen with no history of disease. The sea trout stock were from river Sima (Hardangerfjorden), while the salmon stock were a commercial breed (originally from 2 different rivers on the west coast of Norway). Initial mean weight and length of trout and salmon were $42 \mathrm{~g}$ and $15 \mathrm{~cm}$, and $48 \mathrm{~g}$ and $16 \mathrm{~cm}$, respectively. The fish were acclimatised for $8 \mathrm{~d}$ to particle $(20 \mu \mathrm{m})$ and UVfiltered (Katadyn $\mathrm{J} 1 / \mathrm{P}$, effect: $50 \mathrm{~mW} \mathrm{~cm}^{-2}$ ) seawater $\left(34 \%\right.$ ), kept at $12.5^{\circ} \mathrm{C}$ in $0.15 \mathrm{~m}^{3}$ tanks (flow rate $=5 \mathrm{l}$ $\mathrm{min}^{-1}$; 50 specimens in each tank), and fed commercial pellets twice a day.
The ISAV used in the challenge was collected in vacutainer blood-collecting tubes with sodium heparin in 1992 and 1993 from infected Atlantic salmon Salmo salar in 2 fish farms outside Bergen. The blood had been stored at $-80^{\circ} \mathrm{C}$ before it was sonicated and sterile filtered $(0.2 \mu \mathrm{m})$. The filtrate was diluted $1: 1 \mathrm{in}$ Hanks' balanced salt solution (HBSS). Each fish received an intraperitoneal (i.p.) injection of $0.2 \mathrm{ml}$ of the virus solution and each control fish received an i.p. injection of $0.2 \mathrm{ml} \mathrm{HBSS}$ (Table 1). The fish were challenged on 16 April 1997. After 121 d, 14 August 1997. all groups were submitted to a latent carrier test (LCT), where each of the remaining fish received an i.p. injection of $0.2 \mathrm{ml}$ prednisoloneacetate $(10 \mathrm{mg}$ prednisoloneacetate $\left.\mathrm{ml}^{-1}\right)$.

Several tissues (blood, kidney, spleen, heart and skin) were collected from the trout during the $135 \mathrm{~d}$ period (Table 1). The tissues were frozen in nitrogen and stored at $-80^{\circ} \mathrm{C}$ for later use. Material from the following sampling dates were screened by cell culture, inoculation into disease-free salmon and RT-PCR: 2 May, 7 May, 9 June, 13 August and 29 August (Table 2). Tissues from the same fish were used in the screening by all 3 methods. However, the fish from each sampling date were pooled when screened by cell-culture and transmission into disease-free salmon, while the individual fish were kept separate in the RT-PCR screening.

The following measurements were made of the fish sampled: weight, length, and clinical signs of disease. Blood was collected for haematocrit measurements and blood smears made for study of blood cell morphology. A few selected fish (sea trout) were also examined bacteriologically by inoculation of kidney tissue on blood agar plates which were incubated for $6 \mathrm{~d}$ at $20^{\circ} \mathrm{C}$, and on blood agar plates containing $2 \%$ $\mathrm{NaCl}$ which were incubated for $6 \mathrm{~d}$ at $15^{\circ} \mathrm{C}$.

Table 1 Salmo trutta and S. salar. Experimental groups of sea trout and Atlantic salmon challenged with infectious salmon anaemia virus (ISAV) and control groups challenged with Hanks' balanced salt solution (HBSS). ST = sea trout challenged with ISAV, KT = sea trout challenged with HBSS, SS = Atlantic salmon challenged with ISAV, KS = Atlantic salmon challenged with HBSS. Number in the code is the tank number. Number of fish collected for screening at each date after the start of the experiment is shown. $\mathrm{N}=$ total number of specimens in each group

\begin{tabular}{|c|c|c|c|c|c|c|c|c|c|c|c|c|c|c|}
\hline & & $\begin{array}{l}\text { Apr } 28 \\
\text { Day } 12\end{array}$ & $\begin{array}{l}\text { May } 2 \\
\text { Day } 16\end{array}$ & $\begin{array}{l}\text { May } 7 \\
\text { Day } 21\end{array}$ & $\begin{array}{l}\text { May } 12 \\
\text { Day } 26\end{array}$ & $\begin{array}{l}\text { May } 20 \\
\text { Day } 34\end{array}$ & $\begin{array}{c}\text { May } 30 \\
\text { Day } 44\end{array}$ & $\begin{array}{c}\text { Jun } 3 \\
\text { Day } 49\end{array}$ & $\begin{array}{c}\text { Jun } 9 \\
\text { Day } 54\end{array}$ & $\begin{array}{c}\text { Jul } 8 \\
\text { Day } 83\end{array}$ & $\begin{array}{c}\text { Aug } 13 \\
\text { Day } 119\end{array}$ & $\begin{array}{c}\text { Aug } 29 \\
\text { Day } 135\end{array}$ & Dead & $N$ \\
\hline $1 \mathrm{ST}$ & ISAV & 5 & 5 & 5 & 5 & 5 & 5 & - & 5 & - & 5 & 9 & 1 & 50 \\
\hline $2 S T$ & ISAV & 5 & 5 & 5 & 5 & 5 & 5 & _- & 5 & _- & 5 & 7 & 3 & 50 \\
\hline $3 \mathrm{ST}$ & ISAV & 5 & 5 & 5 & 5 & 5 & 5 & - & 5 & - & 5 & 5 & 5 & 50 \\
\hline $6 \mathrm{KT}$ & HBSS & 5 & 5 & 5 & 5 & 5 & 5 & - & 5 & - & 5 & 7 & 3 & 50 \\
\hline $7 \mathrm{KT}$ & HBSS & 5 & 5 & 5 & 5 & 5 & 5 & - & 5 & - & 5 & 5 & 5 & 50 \\
\hline $8 \mathrm{KT}$ & HBSS & 5 & 5 & 5 & 5 & 5 & 5 & - & 5 & - & 5 & 9 & 1 & 50 \\
\hline $4 S S$ & ISAV & - & - & - & - & - & - & - & - & - & 2 & 3 & 45 & 50 \\
\hline $5 \mathrm{KS}$ & HBSS & - & - & - & - & - & - & 5 & - & 5 & 5 & 5 & 7 & $50^{\circ}$ \\
\hline
\end{tabular}


Table 2. Salmo trutta. Material collected from the trout groups on Days 16, 21, 54, 119 and 135, after challenge was screened by cell culture, inoculation into disease-free salmon, and RT-PCR. The kidney (ST and KT) and blood (ST) tissues were homogenised, cleared by centrifugation, filtered $(0.2 \mu \mathrm{m})$ and diluted 1:100 in PBS before incubation for $3 \mathrm{~h}$ on cell cultures with a mono-layer of ASK cells $\left(80 \mathrm{~cm}^{2}\right)$. The blood (ST) used in the challenge of disease-free salmon was diluted 1:7 with HBSS before intraperitoneal injection

\begin{tabular}{|c|c|c|c|}
\hline Tissue & $\begin{array}{l}\text { ASK cells } \\
(\mathrm{ml})\end{array}$ & $\begin{array}{c}\text { Inoculation into } \\
\text { disease-free salmon (ml) }\end{array}$ & $\begin{array}{l}\text { RT-PCR } \\
\text { (mg) }\end{array}$ \\
\hline Blood & 10.0 & 0.2 & - \\
\hline Kidney & 10.0 & - & $50-100$ \\
\hline
\end{tabular}

Establishment of a salmon kidney cell culture. Pieces of head kidney from a sexually mature female Atlantic salmon Salmo salar L. were homogenised and

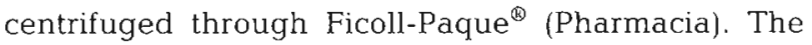
cells on top of the Ficoll fraction was collected and washed by centrifugation and resuspension, and finally resuspended in L-15 medium (BioWittaker) supplemented with FCS $(10 \% \mathrm{v} / \mathrm{v})$, gentamicin $\left(50 \mu \mathrm{g} \mathrm{ml}^{-1}\right)$ and L-glutamine $(4 \mathrm{mM})$. The cells were cultured at $20^{\circ} \mathrm{C}$ in cell culture flasks $\left(25 \mathrm{~cm}^{2}\right.$. Nunc) and nonadherent cells removed after $24 \mathrm{~h}$. The cell culture has now been passed 30 times and is in the text referred to as ASK cells. These cells show a distinct cytopathic effect (CPE), i.e. cell rounding and detachment from the substrate, 7 to $8 \mathrm{~d}$ after inoculation with the ISA virus.

Virus inoculation. Blood and head kidney tissues were kept separate, homogenised, and cleared by centrifugation before filtration $(0.2 \mu \mathrm{m})$. The homogenates were diluted 1:100 in PBS and incubated for $3 \mathrm{~h}$ at $15^{\circ} \mathrm{C}$ in cell culture flasks with a mono-layer of ASK cells (Table 2). The inoculum was then removed and replaced by supplemented L-15 medium as described above, but with $5 \%$ FCS. The cells were incubated at $15^{\circ} \mathrm{C}$ for $12 \mathrm{~d}$ or until CPE could be observed. The medium from cells considered negative after $12 \mathrm{~d}$ was used as inoculum in a passage to new cells. The samples were passed 3 times before they were considered negative. A negative and a positive control cell culture were always included.

Indirect immunofluoresence staining on cell culture. The cells were washed 3 times in PBS pH 7.4 $(0.1 \%$ Tween-20) and fixed in $80 \%$ acetone for 20 min. After complete drying the cells were blocked with $5 \%$ milk powder in PBS for 30 min. The primary mouse anti-ISA monoclonal antibodies (MAb) (3H6F8) diluted 1:150 was inoculated at $4^{\circ} \mathrm{C}$ overnight. The cells were washed 3 times with PBS $(0.1 \%$ Tween-20) before the secondary antibodies fluorescein isothiocyanate (FITC)-labelled goat anti-mouse Ig diluted 1:100 was incubated at $20^{\circ} \mathrm{C}$ for $60 \mathrm{~min}$. The cell nucleus was stained with propidium iodide (Sigma P-4170, $10 \mu \mathrm{g} \mathrm{ml}^{-1}$ ) for $1 \mathrm{~min}$ and washed with PBS Tween 3 times. The stained cell cultures were checked at $\times 1000$ magnification in a Zeiss fluorescense microscope (Axioskop).

Transmission trials. To determine if the virus could be transmitted from the trout to disease-free Atlantic salmon (of the same origin as that used in the first challenge), blood samples collected from the trout groups (21, 54, 119 and $135 \mathrm{~d}$ after challenge) were used to challenge 4 groups of salmon, SS21, SS54, SS119 and SS135, respectively (Table 2). Blood from 5 trout in each group was mixed, sonicated, filtered, and diluted $1: 7$ with HBSS and $0.2 \mathrm{ml}$ injected i.p. into 30 salmon in each of the 4 groups. Group SS21 was challenged on the 20 June 1997 while the other 3 groups (SS54, SS1 19 and SS135) were challenged on the 7 October 1997. The mortality in the 4 salmon groups was registered and samples for RT-PCR diagnosis of ISAV were taken from all 4 groups after $25 \mathrm{~d}$.

RNA extraction. Kidney tissues from the salmon and the trout were homogenised in $1 \mathrm{ml}$ of TRIZOL (Gibco $\mathrm{BRL}$ ) reagent (50 to $100 \mathrm{mg}$ of tissue / $1 \mathrm{ml}$ TRIZOL). The homogenised samples were incubated at $20^{\circ} \mathrm{C}$ for $15 \mathrm{~min}$ (in some cases the samples were stored in TRIZOL at $4{ }^{\circ} \mathrm{C}$ overnight). After incubation, $0.2 \mathrm{ml}$ of chloroform was added per $1 \mathrm{ml}$ of TRIZOL and the tubes were vigorously shaken (Vortex $15 \mathrm{~s}$ ) and incubated for $5 \mathrm{~min}$ at $20^{\circ} \mathrm{C}$. The samples were subsequently centrifuged at $12000 \times g$ for $15 \mathrm{~min}$ at $4^{\circ} \mathrm{C}$. The upper aqueous phase (containing the RNA) was transferred to a fresh tube and the RNA was precipitated by mixing with $0.5 \mathrm{ml}$ isopropyl alcohol. The samples were incubated at $20^{\circ} \mathrm{C}$ for $10 \mathrm{~min}$ and centrifuged at $12000 \times g$ for $15 \mathrm{~min}$ at $4^{\circ} \mathrm{C}$. The RNA precipitated and formed a pellet on the side and bottom of the tube. The supernatant was removed and the pellet washed with $1 \mathrm{ml}$ of $75 \%$ ethanol (the samples were centrifuged at $7500 \times g$ for $5 \mathrm{~min}$ at $4^{\circ} \mathrm{C}$ ). The RNA pellets were briefly dried (<10 min) and dissolved in $50 \mu$ l RNasefree water. Then the RNA solutions were immediately precipitated by adding $100 \mu \mathrm{l}$ of $100 \%$ ethanol and $5 \mu \mathrm{l}$ $3 \mathrm{M} \mathrm{Na}$-Acetate $(\mathrm{pH}=5.2)$. These solution were stored at $-20^{\circ} \mathrm{C}$ for at least $1 \mathrm{~h}$ before centrifugation at $15000 \times g$ for $25 \mathrm{~min}$. The RNA pellets were washed 2 times in $80 \%$ ethanol, dried for $10 \mathrm{~min}$ and dissolved in $50 \mu \mathrm{l}$ RNase-free water. The double wash of the RNA was carried out to reduce the amount of possible inhibitors, from host tissues, to the RT-PCR. The quality and the quantity of the purified nucleic acids were determined by measuring the absorbance $(A)$ at $260 \mathrm{~nm} / 280 \mathrm{~nm}\left(A_{260} / A_{280}\right)$, in a spectrophotometer (Pharmacia Biotech Genequant II). These RNA-solutions were used for RT-PCR. 
RT-PCR. About $1.5 \mu \mathrm{g}$ total RNA + $1.5 \mu \mathrm{l}(1.5 \mu \mathrm{g})$ random hexamers $\left(p d(N)_{6}\right)$ in a total volume of $10 \mu$ l were incubated at $70^{\circ} \mathrm{C}$ for $5 \mathrm{~min}$ and then cooled to $4^{\circ} \mathrm{C}$. RT-mix containing $5.0 \mu \mathrm{l} 5 \times \mathrm{RT}$ buffer $+1.2 \mu \mathrm{l} 200 \mathrm{mM}$ DL-dithiothreitol (DTT) + $2.5 \mu \mathrm{l} 10 \mathrm{mM} \mathrm{dNTP}+0.5 \mu \mathrm{l}$

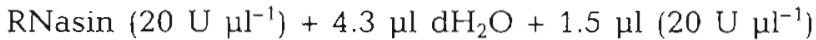
Moloney Murine Leukemia Virus Reverse Transcriptase (MMLV-RT) were added at room temperature, making a total of $25 \mu \mathrm{l}$. This solution was incubated at $37^{\circ} \mathrm{C}$ for 60 min.

XPRIMER (Stew Scherer, Microbiology Department, University of Minnesota) software was used to identify primer pairs corresponding to Segment 8 (Accession no. AJ012285) of the ISA virus (FA-1/RA-1, FA-2/RA-2 and FA-3/RA-3) and to Segment 2 (Accession no. AJ002475), i.e. the RNA-dependent RNA polymerase (RdRp) gene (1.148A/1.148B) (Table 3). The DNA products resulting from amplification gave the expected size for all pairs of sense and antisense primers: FA-1/RA-1 = 416 bp, FA-2/RA-2 $=571$ bp, FA-3/RA-3 = $211 \mathrm{bp}$, and $1.148 \mathrm{~A} / 1.148 \mathrm{~B}=383 \mathrm{bp}$. The most sensitive set of primers, FA-3/RA-3, corresponding to Segment 8 , was used in the RT-PCR screening of the trout.

The PCR consisted of $2 \mu$ l of CDNA-solution that was added to $23 \mu \mathrm{l}$ of reaction mixture consisting of $14.2 \mu \mathrm{l}$ $\mathrm{ddH}_{2} \mathrm{O}, 2.5 \mu \mathrm{l}(\times 10)$ running buffer, $2.0 \mu \mathrm{l}(25 \mathrm{mM}$ $\mathrm{MgCl}), 2 \mu \mathrm{dNTP}(10 \mathrm{mM}), 1.0 \mu \mathrm{l}$ of each primer

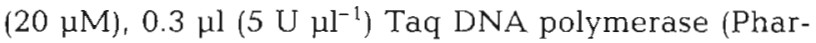
macia Biotech). The mixture was denatured at $94^{\circ} \mathrm{C}$ for $3 \mathrm{~min}$ and amplification was performed with 35 cycles of $94^{\circ} \mathrm{C}$ for $30 \mathrm{~s}, 59^{\circ} \mathrm{C}$ for $45 \mathrm{~s}$, and $72^{\circ} \mathrm{C}$ for $90 \mathrm{~s}$, followed by extension at $72^{\circ} \mathrm{C}$ for $10 \mathrm{~min}$. The tubes were then held at $4^{\circ} \mathrm{C}$. Amplification and reverse transcription were performed in a thermal cycler with a heated lid (TECHNE, Progene). The described protocol for RT-PCR was also compared with a commercial kit, a 1 -step protocol for RT-PCR (Ready-to-go, RT-PCR beads), from Pharmacia Biotech (cf. instructions included in the kit).

Aliquots $(10 \mu l)$ of the $\mathrm{PCR}$ reaction mixture were electrophoresed in $1 \%$ agarose $1 \times$ Tris-Borate-EDTA (TBE) gel containing ethidium bromide stain (GibcoBRL) and photographed under UV transillumination. DNA molecular weight marker type $250 \mathrm{bp}$ DNA ladder was applied to identify the size of the PCR products.

Controls. Primers for MHC-I (Accession no: L07605) were used as positive controls for the RT-PCR (Table 3 ). The DNA products resulting from amplification gave the expected product of about $464 \mathrm{bp}$ (some individual variation), which is the length that will result from a RT-PCR of mRNA templates of MHC-I.

In addition to RNA from trout and Atlantic salmon that were not challenged with ISA virus, negative controls containing $\mathrm{dH}_{2} \mathrm{O}$ instead of RNA or cDNA were used to test each reaction mixture.

Sensitivity. An ISA positive cell culture supernatant was incubated at $4^{\circ} \mathrm{C}$ for $4 \mathrm{~d}$ before $1 \mathrm{ml}$ of supernatant was taken out for end point titration in a 96-well culture plate, using an immunofluorescence assay (cf. Falk et al. 1998). The titration was done using ASK cells and the $50 \%$ tissue culture infective dose $\left(\mathrm{TCID}_{50}\right)$ was estimated. The rest of the supernatant $(49 \mathrm{ml})$ was precipitated with PEG8000 and centrifuged at $6000 \times g$ for $1 \mathrm{~h}$. The supernatant was then removed and the pellet dissolved in $1 \mathrm{mI}$ Trizol for RNA isolation (procedure described earlier). The $49 \mathrm{ml}$ supernatant gave a total of $4600 \mathrm{ng}$ RNA or $184 \mathrm{ng} \mathrm{hl}^{-1}$ after it had been dissolved in $25 \mu \mathrm{RN}$ ase-free water. A 10 -fold dilution series ( $37.0 \mathrm{ng}$ to $3.7 \mathrm{fg}$ ) was made from the RNA and tested in the RT-PCR assay. The cDNA from these reactions were tested by the FA-3/RA-3 primers and $10 \mu \mathrm{l}$ of each reaction was analysed by ethidium bromide-stained gel electrophoresis.

Table 3. Sequence, location, and characterisation of the primers tested for use in RT-PCR amplification of the eighth segment of the ISA virus and the RNA-dependent RNA polymerase (RdRp) gene. The sense (FA-1, FA-2, FA-3 and 1.148A) and antisense (RA-1, RA-2, RA-3 and 1.148B) primers were designed with the help of XPRIMER software. The first 6 primers correspond to Segment 8 (AJ012285) of the ISAV and the 4 others to the RdRp gene (Segment 2: AJ002475) and the MHC-I gene (L07605) of Atlantic salmon. The sequences are given in 5'- 3' polarity

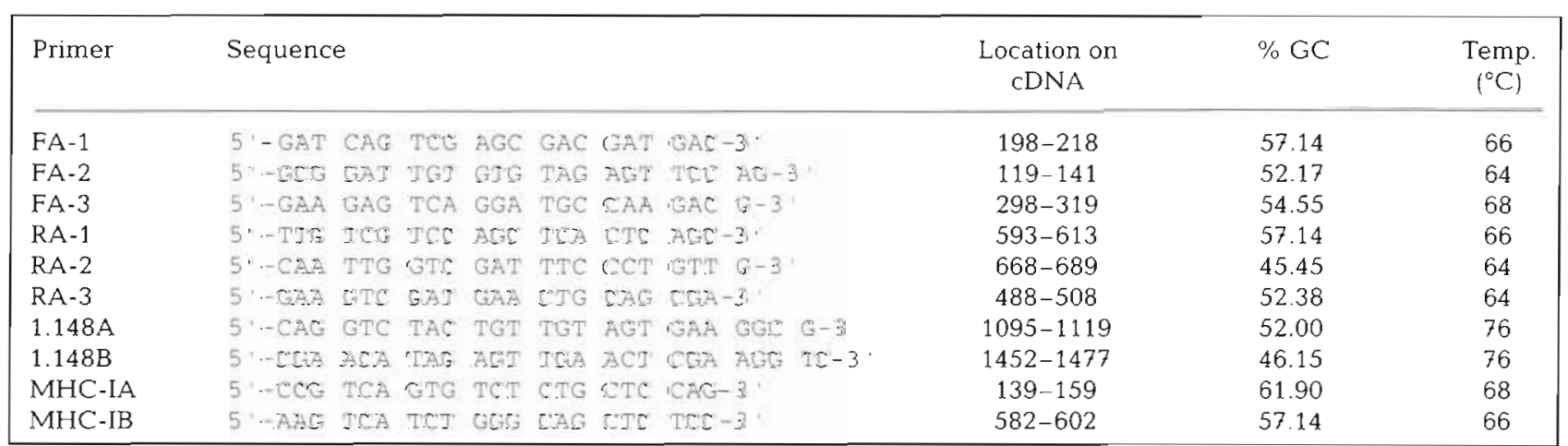


In addition, various amounts of RNA (from $750 \mathrm{ng}$ to $7.5 \mathrm{pg}$ ) from kidney tissues of ISA-challenged salmon were used as templates in a RT-PCR to get additional information about the sensitivity of RT-PCR detection of the virus. The RNA was isolated from an ISAVinfected salmon with a haematocrit of $33 \%$ and no clinical sign of disease. The cDNA from these reactions were tested by the FA-3/RA-3 primers and $10 \mu$ of each reaction was analysed by ethidium bromidestained gel electrophoresis.

The sensitivity of the PCR was tested by using various amounts of dsDNA from $2.2 \mathrm{pg}$ to $2.2 \mathrm{ag}$ as template for the FA-3/RA-3 primers. The dsDNA was produced by primer pair FA-2/RA-2, which give a sequence of $571 \mathrm{bp}$. The number of templates per $\mu \mathrm{l}$ reaction mixture was calculated according to the following formulae: gram dsDNA $\times \mathrm{Av} / \mathrm{Mw}$, where the gram dsDNA was measured at an optical density (OD) of $260 \mathrm{~nm}$, and Av = Avogadro's number and $\mathrm{Mw}=$ the molecular weight of the 571 bp long dsDNA. Each nucleotide was given a weight of 325 Da. Each reaction was analysed by using $10 \mu \mathrm{l}$ of the reaction mixture in ethidium bromide-stained gel electrophoresis.

Specificity. The primer sets (FA-1/RA-1, FA-2/RA-2, FA-3/RA-3) were targeted against the ISA virus sequence published by Mjaaland et al. (1997). The sequence is deposited in the EMBL, GenBank, and DDBJ database under Accession no. Y10404. However, due to errors in the sequence published by Mjaaland et al. (1997) (see also Blake et al. 1999), we re-sequenced the segment from their ISA virus isolate (Glesvær/400/90) and checked the primers against this new sequence (Accession no. AJ012285). The specificity of the primer sets was determined by sequencing the PCR products.

\section{RESULTS}

The mortality was low in all groups after challenge, with the exception of the salmon group (4SS) challenged by the ISA virus. In this group $90 \%$ died within $32 \mathrm{~d}$ after challenge. There was no mortality in this group after Day 32. There were some mortalities $(<10 \%)$ in the other groups after the start of the experiment. Bacteria were isolated from a few of the dead fish, but they were not among the known fish pathogens.

The haematocrit values dropped in all groups after the start of the experiment. However, the drop was largest in the groups challenged with the ISA virus. Haematocrit values as low as 1 (mean $=9$ ) were measured in the salmon challenged by ISAV, while the lowest haematocrit in the control salmon was 30 (mean $=38$, range: 30 to 47 ). After $21 \mathrm{~d}$ the mean haematocrit in the control trout $(\mathrm{N}=15$ ) was 39 (range: 29 to 46 , variance: 28 ), while the haematocrit in the challenged trout ( $N=15$ ) was 34 (range: 22 to 46 , variance: 75 ). However, on Days 26, 34 and 44 after challenge the haematocrit values were about the same in the challenged and control trout groups. The mean haematocrits of control and challenged trout were significantly ( $p<0.05$, Mann-Witney $U$-test) different 119 and $135 \mathrm{~d}$ after the start of the experiment. In the control groups the mean haematocrit were 38 (range: 32 to 45 , variance: 10 ) and 39 (range: 35 to 45 , variance: 7) and in the challenged trout groups 34 (range: 28 to 42 , variance: 17 ) and 36 (range: 28 to 45 , variance: 23) 119 and $135 \mathrm{~d}$ after challenge, respectively.

\section{Cell cultures}

The cell cultures inoculated with filtrate from blood and kidney tissue collected from ISA challenged trout $16,21,54$ and $119 \mathrm{~d}$ after challenge were negative for ISA virus, i.e. no CPE was observed and the immunofluorescent antibody test (IFAT) staining was negative. The culture that was inoculated with kidney tissue collected from trout $135 \mathrm{~d}$ after challenge (16 d after injection of prednisoloneacetate) was clearly positive for ISA virus after the second passage, while the bloodinoculate from the same fish was negative. The positive control cell cultures were positive for ISA virus after $7 \mathrm{~d}$ (first passage). The positive cell cultures showed a distinct CPE and stained positive with the $\mathrm{MAb}$ against the ISA virus (IFAT). The negative controls were negative for ISA virus.

\section{Transmission from trout to salmon}

The salmon (Groups SS21, SS54, SS119 and SS135) that were challenged with blood collected from the ISAchallenged sea trout $21,54,119$ and $135 \mathrm{~d}$ after the start of the experiment became infected (determined by RTPCR), but mortality only occurred in the salmon group challenged with blood collected after $21 \mathrm{~d}$. All fish in group SS21 were dead 30 d after challenge showing clinical signs of ISA. They were also positive for ISA virus in the RT-PCR test. The Groups SS54, SS119 and SS135 were kept for 6 mo, but no mortality was observed. However, they were confirmed positive for the ISA virus $25 \mathrm{~d}$ after challenge with the help of RT-PCR.

\section{RT-PCR}

\section{Sensitivity of detection}

The cell culture titration (ASK cells) gave an infectivity titre of $10^{6.4} \mathrm{TCID}_{50} \mathrm{ml}^{-1}$ supernatant. An amplifica- 


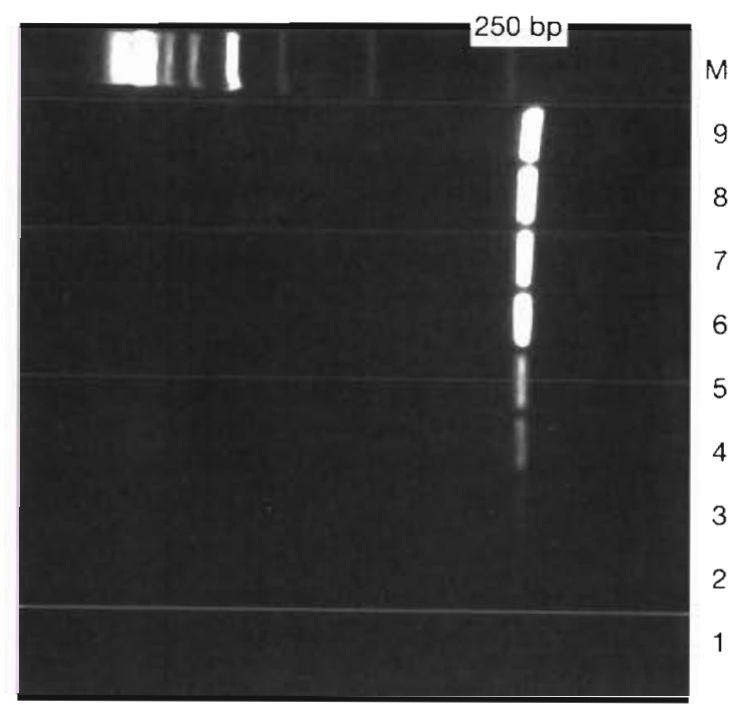

Fig. 1. Demonstration of the threshold of detection of ISA virus by RT-PCR using the FA-3/RA-3 primer set. Agarose gel showing RT-PCR amplification products $(10 \mu \mathrm{l})$ stained by ethidium bromide. DNA marker (M) is a ladder from 250 up to $3000 \mathrm{bp}$ (the steps are $250 \mathrm{bp}$ ); Lanes $1-9$ are RT-PCR products. The amount of RNA used in the RT-PCR ranged from $37.0 \mathrm{ng}$ to $3.7 \mathrm{fg}$; (1) negative control, (2) $3.7 \mathrm{fg}$, (3) $37.0 \mathrm{fg}$, (4) $0.37 \mathrm{pg}$. (5) $3.7 \mathrm{pg}$, (6) $37.0 \mathrm{pg}$, (7) $0.37 \mathrm{ng}$, (8) $3.7 \mathrm{ng}$ and (9) $37.0 \mathrm{ng}$

tion product could be visualised by ethidium bromide staining when as little as $37.0 \mathrm{fg}$ of RNA were used template (Fig. 1).

When as little as $75 \mathrm{pg}$ (1:10000 dilution) RNA from ISA-infected salmon kidney tissue was used as template, the product could be visualised by ethidium bromide staining using $10 \mu \mathrm{l}$ RT-PCR product (Fig. 2). A similar result was achieved by using Ready-To-Go RT-PCR beads.

As little as $0.22 \mathrm{fg}$ dsDNA in the PCR reaction using the FA-3 and RA-3 primers could be visualised by ethidium bromide staining using $10 \mu$ l aliquots (Fig. 3). This would be about 300 templates of DNA in the $25 \mu l$ reaction mixture. However, this band was very weak and in most cases the detection threshold would be between 300 and 3000 templates (cf. Fig. 3).

\section{Specificity of the RT-PCR}

In the specificity tests of the ISA virus RT-PCR assay, use of the sense and antisense primers on control trout and control salmon gave no amplification product. Sequencing of the PCR products from ISA-positive salmon and trout gave sequences that were similar to the target ISA virus sequence for all primer sets. The similarity of the $571 \mathrm{bp}$ long sequence product of FA-2/RA2 primer set was 99.9\% (1 nucleotide differ- ent) compared to our sequence of Segment 8 of the Glesvær isolate (Accession no. AJ012285) of the ISA virus. The FA-1/RA-1 and FA-3/RA-3 primer sets anneal between the FA-2 and RA-2 primers and gave the same sequence similarity to the Glesvæer isolate.

\section{Diagnostic RT-PCR}

Table 4 gives the results of the RT-PCR on kidney tissues from challenged and control trout. None of the control trout were found to be positive for the ISA virus. The percentage of positive trout $16,21,54,119$ and $135 \mathrm{~d}$ after challenge were $33,45,56,64$ and $67 \%$, respectively. The signals detected by electrophoresis of the RT-PCR products from trout were signiticantiy weaker compared to the signals produced by RT-PCR on RNA from ISA-infected salmon (Fig. 4).

\section{DISCUSSION}

PCR is becoming a more and more commonly used tool in detection and diagnosis of fish and shellfish pathogens (Arakawa et al. 1990, Nishizawa et al. 1994, Wongteerasupaya et al. 1997, Chi et al. 1998, Hiney \& Smith 1998, Miller et al. 1998, Nilsen \& Nylund 1998, Nunan et al. 1998, Oshima et al. 1998, Strømmen \& Stone 1998), and universal RT-PCR protocols are being developed for human pathogens (Kuno 1998) and diseases of domesticated mammals (Nunez et al. 1998). The purpose of this work was to develop and test a specific and sensitive RT-PCR for detection of ISAV in experimentally infected carrier trout Salmo trutta and to compare this technique with isolation of the agent in host systems (ASK cells and Atlantic salmon). If successful, the detection of ISAV with the help of RT-PCR would have advantages over culturing the virus in hostsystems in terms of a higher sensitivity and shorter detection time.

The available cell cultures (SHK-1 and ASK cells) that are used for isolation of ISA virus are also susceptible to IPN virus occurring in salmonids (Dannevig et al. 1995, authors' pers. obs.), which means that a CPE cannot be used as a safe diagnosis of the ISA virus (even if the CPE is different for ISA and IPN viruses). The cell cultures had to be stained with antibodies against the ISAV to verify presence of the causal agent. No CPE were observed in the cell cultures inoculated with homogenate from blood or kidney collected from trout $16,21,54$ and $119 \mathrm{~d}$ after challenge with the ISA virus and the cell cultures stained negative (IFAT) for presence of ISA virus. The only trout groups that were positive for ISA virus were collected $135 \mathrm{~d}$ after ISAchallenge and $16 \mathrm{~d}$ after injection of prednisoloneac- 


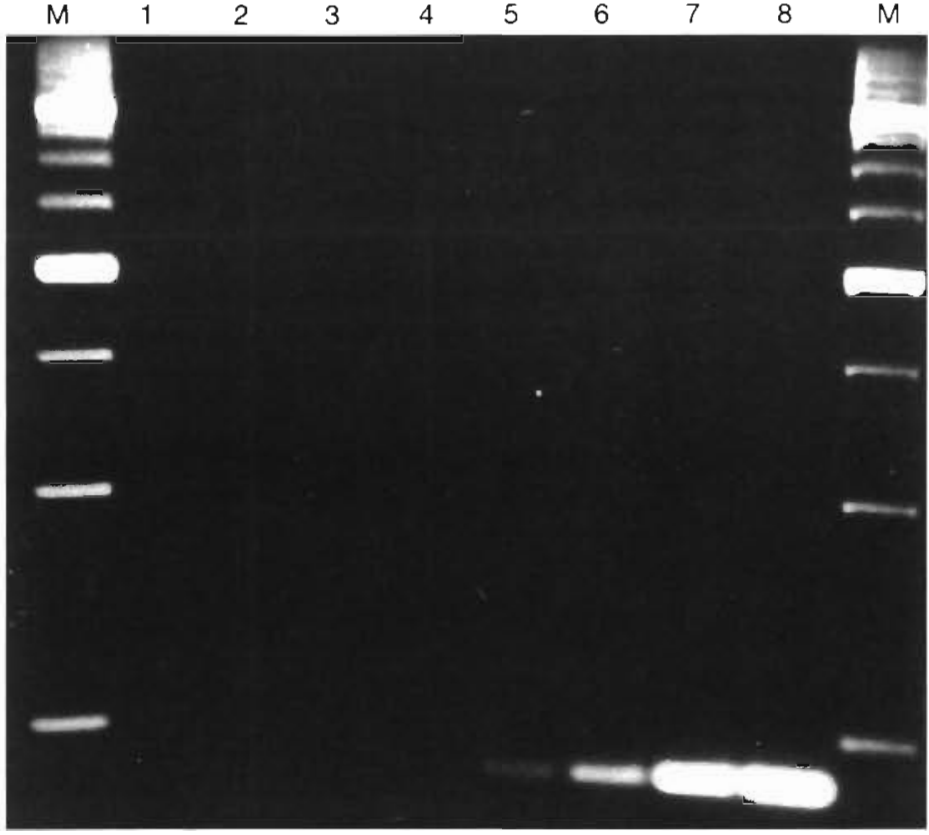

Fig. 2. Demonstration of the threshold of detection of ISA virus in kidney tissue by RT-PCR using the FA-3/RA-3 primer set. Agarose gel showing RT-PCR amplification products $(10 \mu \mathrm{l})$ stained by ethidium bromide. DNA marker (M) is a ladder from 250 up to 3000 bp (the steps are $250 \mathrm{bp}$ ): Lanes 1-8 are RT-PCR products. The amount of RNA used in the RT-PCR ranged from $750 \mathrm{ng}$ to $7.5 \mathrm{pg}$; (1) and (2) negative control, (3) $7.5 \mathrm{pg}$, (4) $75.0 \mathrm{pg}$, (5) $0.75 \mathrm{ng}$, (6) $7.5 \mathrm{ng}$, (7) $75 \mathrm{ng}$ and (8) $750 \mathrm{ng}$ enough to infect the cell cultures. There was no mortality in Groups SS54, SS119 and SS135, but the salmon were positive (RT-PCR) for ISA virus $25 \mathrm{~d}$ after challenge. The difference between Group SS21 and the other 3 groups could be that they were challenged at different times due to practical problems with the availability of experimental tanks. The Groups SS54, SS119 and SS135 were challenged in October while SS21 were challenged in June. Previous studies have shown that a higher dose of ISA virus is necessary to cause mortality when the challenge is carried out in October to January (authors' pers. obs.). It is not known why the salmon seem to be able to better survive challenge with the ISA virus during the winter months.

The primer pairs appeared to be specific for ISA virus RNA, since RT-PCR products of expected size were amplified only when RNA isolated from ISA-infected trout or salmon were used as template. No amplification product was obtained when using RNA extracted from kidney tissues of healthy trout and salmon. The specificity of the primer sets was also confirmed by sequencing of the PCR products. The chosen primer sets are specific etate. This shows that the ISA virus is present in the challenged trout throughout the experimental period, but the cell culture is not sensitive enough to be used for isolation and diagnosis of the virus in carrier trout. Most virus particles produced in a carrier trout are probably neutralised, and not infective. Injection of prednisoloneacetate probably influences the immune system in such a way that a higher number of infective particles are produced, i.e. enough particles to infect the cell cultures.

Injection of material which could contain ISA virus into Atlantic salmon may give the clinical signs most often observed in connection with an ISA infection, but a safe diagnosis would at least require the use of antibodies for a specific identification of the agent. The injection of filtered kidney homogenate collected from trout $21 \mathrm{~d}$ after challenge with ISA virus into disease-free salmon (Group SS21) resulted in $100 \%$ mortality. This shows that infective particles are present in the trout even if the number is not high

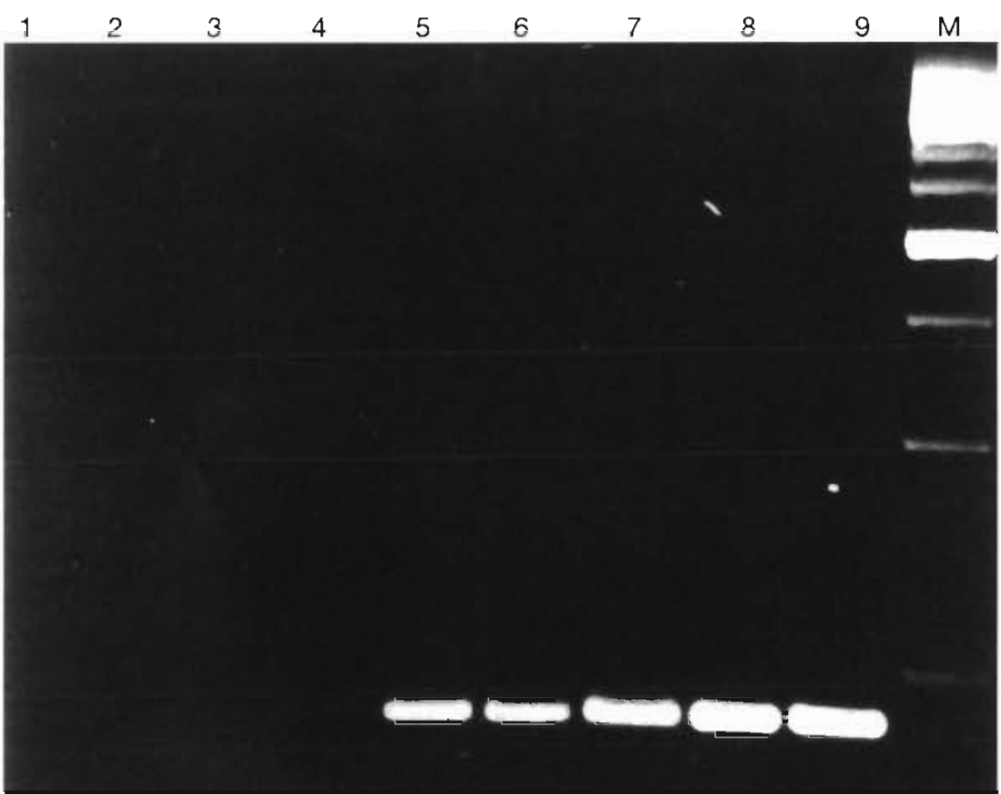

Fig. 3. Demonstration of the threshold of detection of dsDNA (made from ISA virus) by PCR using the FA-3/RA-3 primer set. Agarose gel showing PCR amplification products $(10 \mu \mathrm{l})$ stained by ethidium bromide. DNA marker (M) is a ladder from 250 up to $3000 \mathrm{bp}$ (the steps are $250 \mathrm{bp}$ ). Lanes $1-9$ are PCR products. The amount of dsDNA used in the PCR ranged from $2.2 \mathrm{pg}$ to $0.0022 \mathrm{fg}_{\text {; (1) }}$ and (2) negative control, (3) $2.2 \mathrm{ag}$, (4) $22.0 \mathrm{ag}$, (5) $0.22 \mathrm{fg},(6) 2.2 \mathrm{fg},(7) 22.0 \mathrm{fg},(8) 0.22 \mathrm{pg}$ ) and (9) $2.2 \mathrm{pg}$ 
Table 4. Salmo trutta. Results of the RT-PCR screening of the control and ISAV-challenged trout using the FA-3/RA-3 primer set. The frartion of ISAV-positive fish in the RT-PCR screening is shown. ST = trout groups challenged by ISA virus. $\mathrm{KT}=$ groups of control trout. Number in the code is the tank number

\begin{tabular}{|cccccc|}
\hline & $\begin{array}{c}\text { May 2 } \\
\text { Day 16 }\end{array}$ & $\begin{array}{c}\text { May 7 } \\
\text { Day 21 }\end{array}$ & $\begin{array}{c}\text { Jun 9 } \\
\text { Day 54 }\end{array}$ & $\begin{array}{c}\text { Aug 13 } \\
\text { Day 119 }\end{array}$ & $\begin{array}{c}\text { Aug 29 } \\
\text { Day 135 }\end{array}$ \\
\cline { 1 - 3 } 1ST & $1 / 4$ & $1 / 3$ & $2 / 3$ & $3 / 4$ & $3 / 4$ \\
2ST & $1 / 2$ & $1 / 3$ & $1 / 3$ & $2 / 4$ & $1 / 2$ \\
3ST & $1 / 3$ & $3 / 5$ & $2 / 3$ & $2 / 3$ & $2 / 3$ \\
6KT & $0 / 3$ & $0 / 3$ & $0 / 3$ & $0 / 3$ & $0 / 3$ \\
7KT & $0 / 3$ & $0 / 3$ & $0 / 3$ & $0 / 3$ & $0 / 3$ \\
8KT & $0 / 3$ & $0 / 3$ & $0 / 3$ & $0 / 3$ & $0 / 3$ \\
\hline
\end{tabular}

for the ISA virus and will not pick up any sequences from the fish genome. However, it is not known if the primers can be used for differential diagnosis of viruses closely related to the ISA virus, but they will not pick up sequences from the IPN virus, which is the

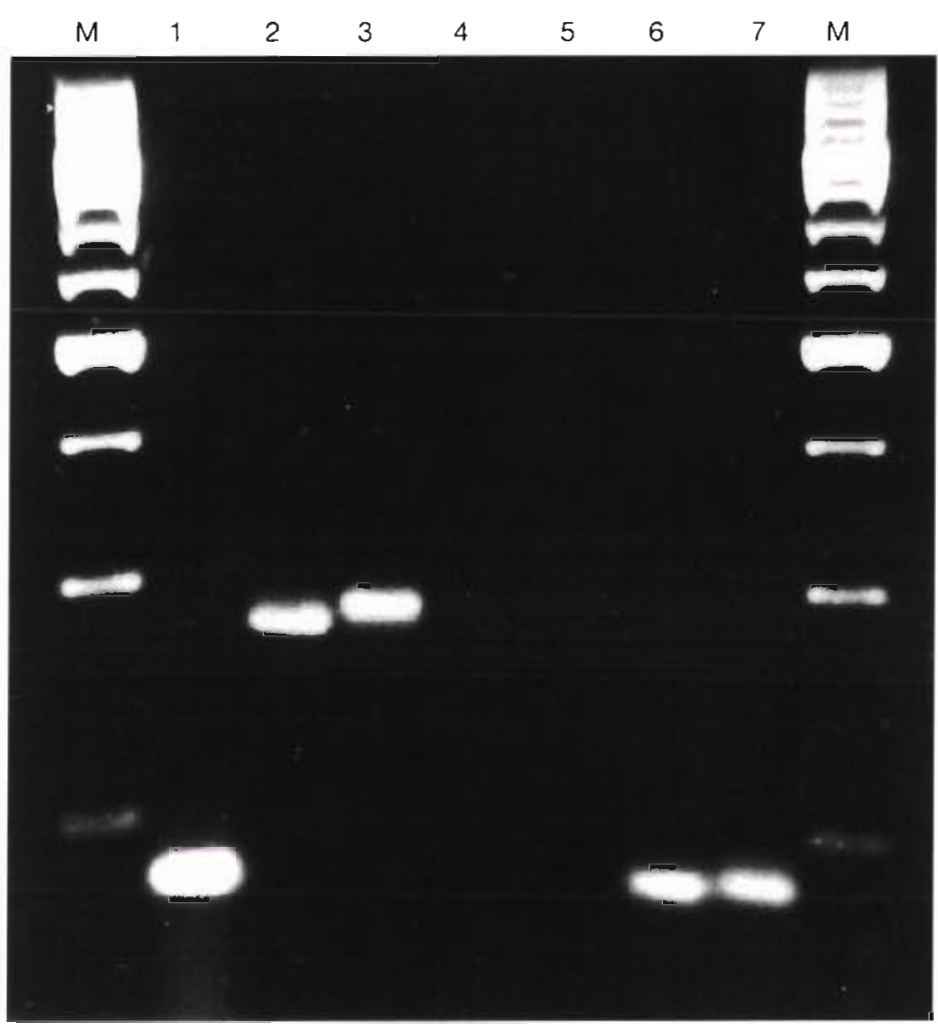

Fig. 4. Agarose gel showing RT-PCR amplification products $(10 \mu l)$ stained by ethidium bromide. DNA marker (M) is a ladder from 250 up to $3000 \mathrm{bp}$ (the steps are $250 \mathrm{bp}$ ). Lane (1) is an ISAV positive control (RNA from the kidney of an ISAV challenged Atlantic salmon). RNA from kidney of control and ISA-challenged trout have been usedin the RT-PCR in lanes 2-7. Lanes 2 and 3 are MHC-I from 2 trouts (primer set MHC-Ia/MHC-Ib). Lanes 4 and 5 are from control trout and lanes 6 and 7 are from ISAV-challenged trout (primer set FA-3/RA-3) virus most likely to occur as a co-infection with ISAV in Norway (authors' pers. obs.). Still, when these primers are used for screening for ISA in other countries than Norway, the product should be sequenced to secure that the product is from an ISA virus, although it is not very likely that the primer set would give a segment of equal size if they anneal to some other virus template. The eighth segment of the ISA virus is conserved enough for the FA-3/RA-3 primer set to be used also for diagnosis of ISA in Atlantic salmon from Scotland and the East Coast of Canada (authors' pers. obs).

Due to difficulties when doing titration to find the number of infective particles (pfu) we had to design a set of different sensitivity tests for the primer sets without this knowledge. In the endpoint titration $\left(\mathrm{TCID}_{50}=\right.$ $10^{6.4} \mathrm{ml}^{-1}$ ) test $37.0 \mathrm{fg}$ viral RNA from the cell culture supernatant could be detected by the RT-PCR (FA-3/ RA-3 primers). Transmission electron microscopy of ISA virus-infected cell cultures have shown that a lot of defective particles (non-infective particles judging from the morphology) are also formed during budding from the cell surface (authors' pers. obs.), which means that the number of virus particles containing the genome is higher than the number of infective particles observed when doing the endpoint titration. When the RT-PCR is carried out on trout tissue, the technique is also able to pick out ISA virus RNA from infected cells, i.e. virus RNA that is still inside infected cells and not in virus particles. Infected cells may contain large amounts of ISA virus genome (cf. Koren \& Nylund 1997). In addition, neutralising antibodies are produced in the trout (Nylund et al. 1994a), which also influences the ratio between infective and non-infective particles. This probably explains why the RT-PCR is more sensitive than the ASK cells in diagnosis of experimentally infected carrier trout (Table 5).

When as little as $75.0 \mathrm{pg}$ RNA from kidney of ISA-challenged Atlantic salmon was used as template for the RT-PCR, an amplification product could be visualised by ethidium bromide staining (primer set FA-3/RA-3). The RNA was extracted from an ISA-challenged salmon with no clinical signs of ISA and a normal haematocrit value. Other salmon in the same tank showed clinical signs of the disease. Lack of clinical signs in the chosen specimen could be indicative of a lower number of infective particles in the tissue used compared to tissues from salmon with clinical disease. This test differs from the previous one in that most of the RNA is host RNA and not ISA virus genome, which explains the difference in sensitivity. Still, this 
Table 5. Salmo trutta. Comparison of the results from the screening for ISAV in trout tissues with the help of cellculture (ASK cells) injection into disease-free salmon (Trans) and RT-PCR. Number of days after challenge of the trout is given in the first column. The column under RT-PCR gives the fraction of ISAV-positive individuals. (+) Positive sample; $(-)$ negative sample

\begin{tabular}{|cccccccc}
\cline { 5 - 7 } Days & \multicolumn{3}{c}{$\begin{array}{c}\text { ISAV-challenged trout (ST) } \\
\text { ASK cells } \\
\text { Blood Kidney }\end{array}$} & \multicolumn{2}{c}{$\begin{array}{c}\text { Control trout (KT) } \\
\text { ASK cells } \\
\text { Kidney }\end{array}$} & RT-PCR \\
\hline 16 & - & - & & $3 / 11$ & - & $0 / 9$ \\
21 & - & - & + & $4 / 11$ & - & $0 / 9$ \\
54 & - & - & $(+)^{\mathrm{a}}$ & $5 / 9$ & - & $0 / 9$ \\
119 & - & - & $(+)^{\mathrm{a}}$ & $7 / 11$ & - & $0 / 9$ \\
135 & - & + & $(+)^{\mathrm{a}}$ & $6 / 9$ & - & $0 / 9$
\end{tabular}

${ }^{a}$ No mortality occurred, but the fish sampled after $25 \mathrm{~d}$ were found to be positive for ISAV with the help of RT-PCR

test gives an indication of the amount of RNA that is necessary for detecting ISA-positive tissues.

Nishizawa et al. (1994) found that 35 PCR incubation cycles made it possible to detect a quantity of striped jack NNV RNA down to a level of approximately $0.1 \mathrm{fg}$ (the DNA product was about $430 \mathrm{bp}$ ), and Wongteerasupaya et al. (1997) showed in an RT-PCR-based detection of yellow-head virus of Penaeus monodon that $10.0 \mathrm{fg}$ of purified YHV RNA could be demonstrated. In a study of foot-and-mouth disease virus the detection limit for the RT-PCR (30 to 40 cycles) was determined to be $10^{4}$ template molecules (Niedbalski et al. 1998). The threshold of detection for our primer set (FA-3/RA-3) is slightly higher than the results presented in these studies.

The sensitivity test of the PCR reaction shows that between 300 and 3000 templates (or between 0.22 and $2.2 \mathrm{fg}$ dsDNA) is enough to give a positive result using the described protocol. Oshima et al. (1998) found that 30 PCR cycles were enough to detected a $187 \mathrm{bp}$ DNA fragment from samples containing as little as $10 \mathrm{fg}$ of DNA (which corresponds to approximately $2000 \mathrm{~mol}$ of a $3800 \mathrm{bp}$ plasmid). In a study of the PCR detection limit of sporoplasma cells from Myxobolus cerebralis using primers against a part (415 bp) of the repetitive $18 \mathrm{~S}$ rDNA, Andree et al. (1998) were able to detect as little as a single cell. However, the number of copies (which may be very high) of $18 \mathrm{~S}$ rDNA in a single cell of $M$. cerebralis is not given. Even if contaminating host chromosomal DNA and other tissue contaminants may decrease the sensitivity of our PCR, the threshold of detection for our primer set (FA-3/RA-3) in the PCR seem to be in accordance with the sensitivity presented in the above-mentioned studies.

The RT-PCR performed directly on RNA from kidney of infected trout was the most sensitive method for detection of ISA-carrying trout. Similar results, i.e.
RT-PCR as the most sensitive diagnostic method, have been found in other studies of RNA viruses infecting fish, other vertebrates, and shellfish, i.e. VHSV and IHNV (Miller et al. 1998), striped jack nervous necrosis virus (Nishizawa et al. 1994), human coronaviruses, 229E and OC43 (Sizun et al. 1998), and Taura syndrome virus (Nunan et al. 1998). Direct examination of tissues by means of RT-PCR is an effective and powerful assay for detecting ISAV in experimentally infected carrier trout and has advantages over the other methods in speed and sensitivity.

Virus survival in nature requires continuous infection of susceptible individuals or establishment of long-term persistence within infected hosts (Fields et al. 1996). During acute infections, virus is cleared by the host immune response, necessitating rapid transmission or capacity for extra-organismal survival. Persistence of virus within an individual host usually starts with an acute infection that progresses to latent or chronic infection, during which the virus is transmitted periodically to new hosts. Previous transmission trials seem to indicate that acute infections in Salmo salar is followed by viral clearance (authors' pers. obs.), while a chronic infection seem to be established in S. trutta (Nylund et al. 1995b). This is also confirmed by the present study. There may, however, be individual differences within those 2 species. Salmon that are experimentally infected are usually ISA negative after $135 \mathrm{~d}$; however, in one case a maturing Atlantic salmon (male) was found positive for ISA virus (RT-PCR) several months after challenge. This could indicate that the RT-PCR is not sensitive enough to pick out ISAcarrying salmon, i.e. there are fewer cells infected and fewer particles produced in asymptomatic salmon than in carrier trout. An experimental study of Atlantic salmon surviving an ISA challenge should be performed to establish what percentage of salmon can act as carriers in a population. This study should also give an indication of the importance of stress like sexual maturation (cf. Nylund et al. 1995b) and salmon lice (cf. Nylund et al. 1993, Rolland \& Nylund 1998) as a factor that may increase the ISA virus production.

Acknowledgement. We are greatly indebted to Knut Falk, National Veterinary Institute, for doing the endpoint titration $\left(\mathrm{TCID}_{50}\right)$.

\section{LITERATURE CITED}

Andree KB, MacConnell E, Hedrick RP (1998) A nested polymerase chain reaction for the detection of genomic DNA. of Myxobolus cerebralis in rainbow trout Oncorhynchus mykiss. Dis Aquat Org 34:145-154

Arakawa CK, Deering RE, Higman KH, Oshima KH, O'Hara PJ, Winton JR (1990) Polymerase chain reaction (PCR) amplification of a nucleoprotein gene sequence of infectious hematopoietic necrosis virus. Dis Aquat Org 8:165-170

Blake S, Bouchard D, Keleher W, Opitz M, Nicholson BL 
(1999) Genomic relationships of the North American isolate of infectious salmon anemia virus (ISAV) to the Norwegian strain of ISAV. Dis Aquat Org 35:139-144

Chi SC, Lo BJ, Lo CF, Kou GH, Chen SN (1998) Detection of nervous necrosis virus (NNV) in the eggs, larvae and juveniles of hatchery reared grouper in Taiwan by polymerase chain reaction. In: Barnes AC, Davidson GA, Hiney MP, McIntosh $D$ (eds) Methodology in fish diseases research. Fisheries Research Services, Aberdeen, p 259-264

Dannevig BH, Falk K, Namork E (1995) Isolation of the causal virus of infectious anaemia (ISA) in a long-term cell line from Atlantic salmon head kidney. J Gen Virol 76:1353-1359

Falk K, Namork E, Rimstad E, Mjaaland S, Dannevig BH (1997) Characterisation of infectious salmon anemia virus, an orthomyxo-like virus isolated from Atlantic salmon (Salmo salar L.). J Virol 71:9016-9023

Falk K, Namork E, Dannavig BH (1998) Characterization and application of a monoclonal antibody against infectious salmon anaemia virus. Dis Aquat Org 34:77-85

Fields BN, Knipe DM, Howley PM (1996) Virology. Lippincott-Raven Publishers, Philadelphia

Hiney M, Smith P (1998) DNA-based diagnostics in aquaculture: can we overcome the problems of interpretation in the field. In: Barnes AC, Davidson GA, Hiney MP, MCIntosh $D$ (eds) Methodology in fish diseases research. Fisheries Research Services, Aberdeen, p 143-159

Hovland T, Nylund A, Watanabe K, Endresen C (1994) Observation of infectious salmon anaemia virus (ISAV) in Atlantic salmon (Salmo salar L.). J Fish Dis 17:291-296

Koren CWR, Nylund A (1997) Morphology and morphogenesis of infectious salmon anaemia virus replicating in the endothelium of Atlantic salmon Salmo salar L. Dis Aquat Org 29:99-109

Krossøy B, Hordvik I, Nilsen F, Nylund A, Endresen C (1999) The putative polymerase sequence of infectious salmon anaemia virus suggests a new genus within the Orthomyxoviridae. J Virol 73(3):2136-2142

Kuno G (1998) Universal diagnostic RT-PCR protocol for arboviruses. J Virol Methods 72:27-41

Kvenseth AM (1998) Wrasse-do they transfer diseases to salmon? Caligus 5:2-4

Miller TA, Rapp J, Wastlhuber U, Hoffmann RW, Enzmann, PJ (1998) Rapid and sensitive reverse transcriptase-polymerase chain reaction based detection and differential diagnosis of fish pathogenic rhabdoviruses in organ samples and cultured cells. Dis Aquat Org 34:13-20

Mjaaland S, Rimstad E, Falk K, Dannevig BH (1997) Genomic characterization of the virus causing infectious salmon anemia in Atlantic salmon (Salmo salar L.): an orthomyxolike virus in a teleost. J Virol 71:7681-7686

Mullins JE, Groman D, Wadowska D (1998) Infectious salmon anaemia in salt water Atlantic salmon (Salmo salar L.) in New Brunswick, Canada. Bull Eur Assoc Fish Pathol 18(4): $110-114$

Niedbalski W, Adam KH, Marquardt O (1998) Quantitation of foot-and-mouth disease virus genomes in bovine tissue by competitive RT-PCR. J Virol Methods 72:237-242

Nilsen F, Nylund A (1998) Identification of virus and parasites. In: Barnes AC, Davidson GA, Hiney MP, McIntosh D (eds) Methodology in fish diseases research. Fisheries Research Services, Aberdeen, p 227-240

Nishizawa T, Mori K, Nakai T, Furusawa I, Muroga K (1994) Polymerase chain reaction (PCR) amplification of RNA of striped jack nervous necrosis virus (SJNNV). Dis Aquat Org 18:103-107

Nunan LM, Poulos BT, Lightner DV (1998) Reverse transcription polymerase chain reaction (RT-PCR) used for the detection of Taura syndrome virus (TSV) in experimentally infected shrimp. Dis Aquat Org 34:87-91

Nunez JI, Blanco E, Hernandez T, Gomez-Tejedor C, Martin MJ, Dopazo J, Sobrino F (1998) A RT-PCR assay tor the differential diagnosis of vesicular viral diseases of swine. J Virol Methods 72:227-235

Nylund A, Jakobsen P (1995) Sea trout as a carrier of infectious salmon anaemia virus. J Fish Biol 47:174-176

Nylund A, Wallace C, Hovland T (1993) The possible role of Lepeophtheirus salmonis in the transmission of Infectious Salmon Anaemia. In: Boxshall G (ed) Pathogens of wild and farmed fish: sea lice. Ellis Horwood Ltd, Chichester, p $367-373$

Nylund A, Alexandersen S, Løvik P, Jakobsen P (1994a) The response of brown trout (Salmo trutta L.) to repeated challenge with infectious salmon anaemia (ISA). Bull Eur Assoc Fish Pathol 14(5):167-170

Nylund A, Hovland T, Hodneland K, Nilsen F, Løvik P (1994b) Mechanisms tor transmission of infecilous sahinoin ànãemia (ISA). Dis Aquat Org 19:95-100

Nylund A, Hovland T, Watanabe K, Endresen C (1995a) Presence of infectious salmon anaemia virus (ISAV) in different organs of Salmo salar L. collected from three fish farms. J Fish Dis 18:135-145

Nylund A, Alexandersen S, Jakobsen P, Rolland JB (1995b) Infectious salmon anaemia (ISA) in brown trout. J Aquat Anim Health $7: 236-240$

Nylund A, Kvenseth AM, Krossøy B (1995c) Suceptibility of wild salmon (Salmo salar L.) to infectious salmon anaemia (ISA). Bull Eur Assoc Fish Pathol 15(5):152-156

Nylund A, Krossøy B, Watanabe K, Holm JA (1996) Target cells for the ISA virus in Atlantic salmon (Salmo salar L.). Bull Eur Assoc Fish Pathol 16(2):68-72

Nylund A, Kvenseth AM, Krossay B, Hodneland K (1997) Rainbow trout (Onchorhynchus mykiss, Walbaum, 1792): a carrier of infectious salmon anaemia (ISAV). J Fish Dis 20: $275-279$

Oshima S, Hata J, Hirasawa N, Ohtaka T, Hirono I, Aoki T, Yamashita S (1998) Rapid diagnosis of red sea bream iridovirus infection using the polymerase chain reaction. Dis Aquat Org 32:87-90

Rodger HD, Turnbull T, Muir F, Millar S, Richards RH (1998) Infectious salmon anaemia (ISA) in the United Kingdom. Bull Eur Assoc Fish Pathol 18(4):115-116

Rolland JB, Nylund A (1998) Sea running trout: carrier and transmitter of the infectious salmon anemia virus (ISAV). Bull Eur Assoc Fish Pathol 18(2):1-6

Sizun J, Arbour N, Talbot PJ (1998) Comparison of immunofluorescence with monoclonal antibodies and RT-PCR for detection of human coronaviruses $229 \mathrm{E}$ and OC43 in cell culture. J Virol Methods 72:145-152

Strømmen HK, Stone DM (1998) Detection of viral haemorrhagic septicaemia (VHS) virus in fish tissues by seminested polymerase chain reaction (PCR). In: Barnes AC, Davidson GA, Hiney MP, McIntosh D (eds) Methodology in fish diseases research. Fisheries Research Services, Aberdeen, p 203-209

Thorud K, Djupvik HO (1988) Infectious anaemia in Atlantic salmon (Salmo salar L.). Bull. Eur Assoc Fish Pathol 8(5): $109-111$

Thorud K, Torgersen Y (1994) Regnbueørret ag sjøorret kan være passive smittebærere av ILA. Norsk Fiskeoppdrett 11A:54-55 (in Norwegian)

Wongteerasupaya C, Tongchuea W, Boonsaeng V, Panyim S, Tassanakajon A, Withyachumnarnkul B, Flegel TW (1997) Detection of yellow-head virus (YHV) of Penaeus monodon by RT-PCR amplification. Dis Aquat Org 31:181-186 